\title{
GUANGALA HUMAN REMAINS FROM THE TORRE MARINA SITE, COASTAL ECUADOR
}

\author{
RESTOS HUMANOS DEL SITIO TORRE MARINA CULTURA GUANGALA, COSTA \\ ECUATORIANA
}

Douglas H. Ubelaker ${ }^{1}$ and Cassandra M. DeGaglia ${ }^{1}$

\begin{abstract}
Comparative skeletal and dental data from periods spanning pre- and post-contact Ecuador reveal trends in the health of populations through time and across geographic regions. This paper presents new data from the Late Guangala site of Torre Marina near La Libertad on the Ecuadorean coast. The sample is comprised of 79 individuals, of all ages, from 57 rasgos (features). Although fragmentary, the recovered remains provide information about the demographic composition of this coastal population as well as the prevalence of trauma and disease. The new data are presented for comparison alongside previously reported statistics from early Ecuador.
\end{abstract}

Key words: Bioarchaeology, precontact Ecuador, population data.

La comparación de datos esqueléticos y dentales que comprenden el Ecuador pre- y post-colombino revelan tendencias en la salud de las poblaciones a través de tiempo y a lo largo de las regiones geográficas. Este artículo presenta nuevos datos del sitio de Torre Marina, ubicado en la tardía Guangala cerca de La Libertad en la costa Ecuatoriana. La muestra está compuesta por 79 individuos, de todas las edades, de 57 rasgos (características). Aunque fragmentados, los restos recuperados proporcionan información sobre la composición demográfica de esta población costera, así como sobre la prevalencia de traumatismos y enfermedades. Los nuevos datos se presentan para su comparación con las estadísticas previamente descritas sobre el Ecuador antiguo.

Palabras claves: bioarqueología, Ecuador precolombino (precolonial), datos de población.

In recent decades, biological analysis of human remains recovered from archeological contexts in Ecuador have yielded a wealth of information regarding health, disease, quality of life, and other variables (Ubelaker 1995; Ubelaker and Newson 2002). Samples examined range temporally from the preceramic site of Las Vegas on the southern coast (Ubelaker 1980a) to historic churches (Ubelaker 1994a) and other institutions (Ubelaker and Rousseau 1993) in the highland city of Quito (Ubelaker 1995). Although most publications focus on samples from southern coastal sites (Ubelaker 1988a, 1988b, 2003), data are also available from the northern coast (Ubelaker 1988c, 1997) and highlands (Ubelaker 1980b, 1988d, 1990a, 1990b, 2000; Ubelaker et al. 1995). Analysis reveals some geographical variation but mostly suggests a gradual, broad temporal increase in morbidity and mortality (Ubelaker 1992a). Prior to European contact, the negative health trend seems to stem from problems of sanitation and nutrition relating to horticulture and population sedentism (Ubelaker 1984). Following European contact, these problems were exacerbated by the arrival of new European based diseases and social upheaval (Ubelaker 1994b, 2003, 2007).

Although the array of sites and samples analyzed present data on the full range of the Ecuadorean past, little has been published regarding the Guangala period of the Ecuadorean coast. The only published Guangala sample originates from OGSE-MA-172, an Early Guangala cemetery site (Ubelaker 1983). This sample of 30 individuals dates from about $2050 \mathrm{BP}$ and presents evidence of porotic hyperostosis likely related

\footnotetext{
${ }^{1}$ Department of Anthropology, National Museum of Natural History. Smithsonian Institution, Washington, D.C., United States. ubelaked@si.edu; degagliac@si.edu
}

Recibido: julio 2018. Aceptado: marzo 2019. 
to hookworm infestation (Ubelaker 1992b). The current report provides new perspectives from the analysis of a Late Guangala sample from coastal Ecuador.

In addition to the bioarchaeological information cited above, the published record also presents considerable archeological information from coastal Ecuador (e.g. Piperno and Stothert 2003; Stothert 1983, 1985; Stothert et al. 2003; Tellkamp 2019). These studies indicate that by the time of the Guangala period in coastal Ecuador, the populations had shifted subsistence toward agricultural products with increasing sedentism. In combination, the skeletal biology and archeological data suggest that morbidity and mortality likely were increasing due to the enhanced opportunity for infectious disease related to sedentism and increased community size. The Torre Marina sample offers an opportunity to examine the health effects of community living in the Guangala period of coastal Ecuador.

\section{Methods}

In July and August 2014, the first author conducted analysis of human remains recovered from archeological excavations at the Torre Marina site, coastal Ecuador. The remains had been excavated under the direction of Ecuadorean archaeologists Javier Lopez and Telmo Lopez Muñoz. Associated artifacts suggested to the archaeologists that the remains dated from the Guangala Phase of the Regional Development/Integration Period. The Guangala Phase dates between approximately 2050 to 950 BP (Reitz and Masucci 2004). The excavation was initiated due to an imminent construction project in the area. The site is located within the city of $\mathrm{La}$ Libertad, coastal Ecuador (Figure 1).

The skeletal analysis was conducted at the invitation of the site archaeologists and Dr. Karen Stothert, who maintains an interest in archaeological developments in the area. Analysis was conducted at Dr. Stothert's laboratory in Cautivo, which is located near La Libertad. Dr. Stothert worked closely with the first author during the analysis, especially in the unpacking, cleaning, washing, drying, photographing, and repackaging of the remains.

References to the bioarchaeological features use the language that was associated with each set of remains provided by archaeologists. Prior to the analysis, the remains were washed with water using soft brushes. Drying was conducted in the shade to avoid damage due to sun exposure. All methods relating to the estimation of age at death and sex follow the recommendations and data provided by Buikstra and Ubelaker (1994) and Ubelaker (1999).

Calculations from Ubelaker (1999) were used to construct a life table (Table 1) for the population. The decimal values reported in column Dx of the life table reflect the number of deaths per age interval, including the proportional assignment of individuals whose ages could only be estimated generally (Ubelaker 2001). For details on methods on life table construction, see Ubelaker (1999).

Dental observations included the number of teeth present, those absent antemortem, the presence of alveolar abscesses, carious lesions, enamel hypoplasia, and the presence and extent of calculus deposits (Ubelaker and Freire 2005). When present, calculus deposits were noted as being small, medium, or large. Additionally, dental attrition was used in conjunction with skeletal indicators to estimate age at death for individuals in the sample. The extent of dental attrition can be used to estimate age by determining the rate of attrition in the individual through examination of the relative amount of occlusal wear on each of the molars (Ubelaker 1999)

The following presents a detailed account of the skeletal analysis, followed by interpretive summaries.

\section{Results}

Detailed feature analysis revealed that at least 79 individuals were present in the 57 archeologicallydesignated rasgos (Table 2). Of these, 24 (30.38\%) were below the age of 10 years. Of the 55 adults in the sample, sex could be estimated reliably for only 32,16 males and 16 females. Human remains were generally in a very fragmentary condition which complicated determination of various aspects of a biological profile for some individuals.

The life table (Table 2) reveals a life expectancy at birth of about 29 years. Life expectancy at age 15 was only about 19 years, with few individuals living beyond the age of 50 . Note however, that ages of death of the elderly are difficult to estimate from fragmentary remains.

A total of 395 teeth (both in place in alveolar bone and loose) were recorded from the sample, 352 permanent teeth and 43 deciduous. Of the permanent teeth recovered, 190 were associated with male remains, 123 were associated with female remains, and 39 were associated with remains of indeterminate sex. Data for deciduous teeth (Table 3) are presented separately from those of permanent teeth (Table 4). No examples of abnormal antemortem tooth loss were noted on immature remains. Carious lesions and alveolar abscesses were also absent in association with deciduous dentition. Many deciduous teeth displayed calculus deposits, evenly distributed on the buccal and lingual surfaces.

Detailed data on conditions of permanent teeth are presented in Table 4 . Of the 352 permanent teeth present, $40(11.36 \%)$ were carious. Of the carious teeth, 


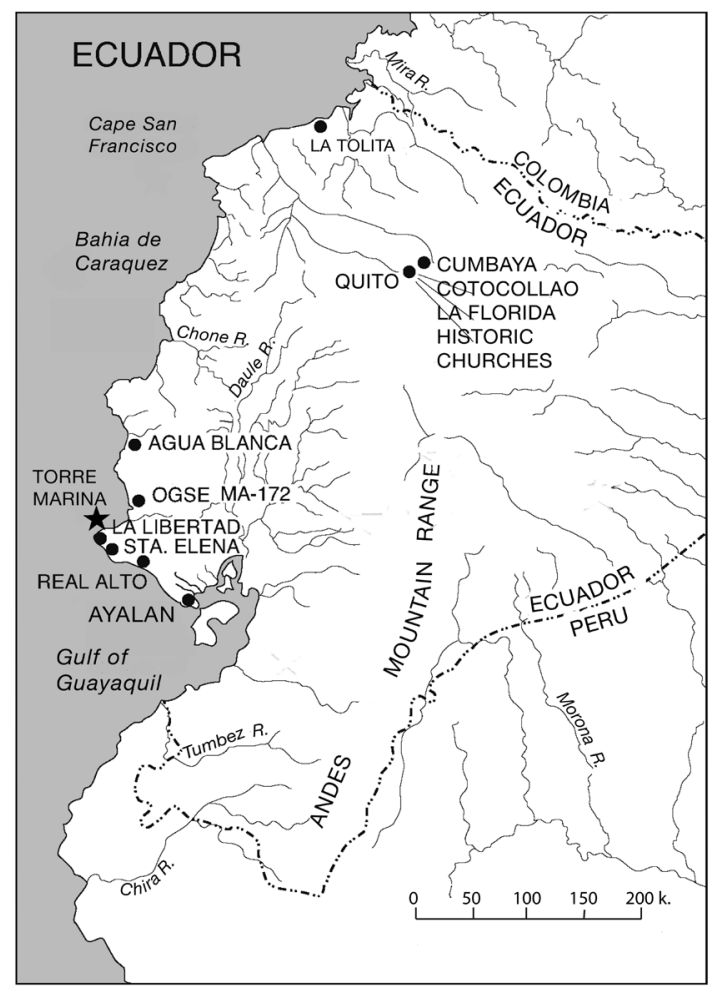

Figure 1: Location of the Torre Marina site in Ecuador.

Localización del sitio Torre Marina en Ecuador.

Table 1. Life table for the Torre Marina population.

Tabla de vida para la población de Torre Marina.

\begin{tabular}{llllllll}
\hline $\begin{array}{l}\text { Age } \\
\begin{array}{l}\text { Interval } \\
(\mathrm{x})\end{array}\end{array}$ & $\begin{array}{l}\text { No. } \\
\text { Deaths } \\
(\mathrm{Dx})\end{array}$ & $\begin{array}{l}\% \\
\text { Deaths } \\
(\mathrm{dx})\end{array}$ & $\begin{array}{l}\text { Survivors } \\
\text { Entering } \\
(\mathrm{lx})\end{array}$ & $\begin{array}{l}\text { Probability } \\
\text { of Death } \\
(\mathrm{qx})\end{array}$ & $\begin{array}{l}\text { Total years } \\
\text { Lived Between } \\
\mathrm{x} \& \mathrm{x}+5(\mathrm{Lx})\end{array}$ & $\begin{array}{l}\text { Total Years } \\
\text { Lived After } \\
\text { Lifetime (Tx) }\end{array}$ & $\begin{array}{l}\text { Life } \\
\text { Expectancy } \\
\text { (Eox) }\end{array}$ \\
\hline $0-0.9$ & 17,00 & 21,52 & 100,00 & 0,22 & 446,20 & 2863,80 & 28,64 \\
\hline $1-4.9$ & 5,50 & 6,96 & 78,48 & 0,09 & 375,00 & 2417,60 & 30,81 \\
\hline $5-9.9$ & 1,50 & 1,90 & 71,52 & 0,03 & 352,85 & 2042,60 & 28,56 \\
\hline $10-14.9$ & 0,00 & 0,00 & 69,62 & 0,00 & 348,10 & 1689,75 & 24,27 \\
\hline $15-19.9$ & 0,00 & 0,00 & 69,62 & 0,00 & 348,10 & 1341,65 & 19,27 \\
\hline $20-24.9$ & 5,58 & 7,07 & 69,62 & 0,10 & 330,43 & 993,55 & 14,27 \\
\hline $25-29.9$ & 11,58 & 14,66 & 62,55 & 0,23 & 276,10 & 663,13 & 10,60 \\
\hline $30-34.9$ & 16,83 & 21,31 & 47,89 & 0,44 & 186,18 & 387,03 & 8,08 \\
\hline $35-39.9$ & 9,87 & 12,49 & 26,58 & 0,47 & 101,68 & 200,85 & 7,56 \\
\hline $40-44.9$ & 4,37 & 5,53 & 14,09 & 0,39 & 56,63 & 99,18 & 7,04 \\
\hline $45-49.9$ & 4,37 & 5,53 & 8,56 & 0,65 & 28,98 & 42,55 & 4,97 \\
\hline $50-54.9$ & 1,45 & 1,84 & 3,03 & 0,61 & 10,58 & 13,58 & 4,48 \\
\hline $55-59.9$ & 0,95 & 1,20 & 1,20 & 1,00 & 3,00 & 3,00 & 2,50 \\
\hline $60-64.9$ & 0,00 & 0,00 & 0,00 & 0,00 & 0,00 & 0,00 & \\
\hline Total & 79,00 & 100,00 & & & & & \\
\hline
\end{tabular}


Table 2. Demographic data by feature.

Datos demográficos por rasgo.

\begin{tabular}{|c|c|c|c|c|c|c|c|c|}
\hline \multirow[b]{2}{*}{ Feature } & \multicolumn{8}{|c|}{ Individuals } \\
\hline & Subadult & Subadult Age & Male & Male Age & Female & Female Age & $\begin{array}{l}\text { Indeterminate } \\
\text { Sex }\end{array}$ & $\begin{array}{l}\text { Indeterminate } \\
\text { Sex Age }\end{array}$ \\
\hline Rasgo 5 & & & & & 1 & $40-50$ & & \\
\hline R6 & & & & & 1 & $30-35$ & & \\
\hline B-R7 & & & 1 & $25-30$ & & & & \\
\hline $\mathrm{R} 8$ & 1 & $0.5 \mathrm{yrs}$ & & & 1 & $20-25$ & & \\
\hline R9 & & & & & & & 1 & $35-60$ \\
\hline \multirow[t]{3}{*}{ R10 } & 1 & $<0.5 \mathrm{yrs}$ & & & & & 1 & $25-30$ \\
\hline & 1 & $1-4$ yrs & & & & & 1 & $30-35$ \\
\hline & 1 & $4-10 \mathrm{yrs}$ & & & & & 1 & $30-50$ \\
\hline \multirow[t]{2}{*}{ R11 } & & & & & 1 & $25-30$ & & \\
\hline & & & & & 1 & $25-30$ & & \\
\hline R13 & & & 1 & $25-30$ & & & & \\
\hline \multirow[t]{2}{*}{ R15 } & & & 1 & $30-35$ & & & & \\
\hline & & & 1 & $30-35$ & & & & \\
\hline R16 & & & 1 & $30-35$ & & & & \\
\hline R17 & 1 & $<0.5 \mathrm{yrs}$ & & & & & & \\
\hline R18 & 1 & $<0.5 \mathrm{yrs}$ & & & & & 1 & $20-40$ \\
\hline R21 & & & & & 1 & $20-35$ & & \\
\hline R25 & 1 & $6 \mathrm{yrs}$ & & & & & & \\
\hline R27 & & & 1 & $20-25$ & & & & \\
\hline \multirow[t]{2}{*}{ B4-R28 } & & & & & & & 1 & $30-35$ \\
\hline & & & & & & & 1 & $35-50$ \\
\hline R29 & & & 1 & $30-35$ & & & & \\
\hline R30 & 1 & $<0.5 \mathrm{yrs}$ & & & & & & \\
\hline R36 & & & & & & & 1 & $20-50$ \\
\hline R37 & 1 & $\begin{array}{l}\text { Fetal }-<0.5 \\
\text { yrs }\end{array}$ & & & & & 1 & $30-40$ \\
\hline R43 & & & & & 1 & $35-40$ & 1 & $45-55$ \\
\hline R46 & 1 & $<0.5 \mathrm{yrs}$ & & & & & & \\
\hline R48 & & & & & 1 & $30-35$ & & \\
\hline R50 & 1 & $<0.5 \mathrm{yrs}$ & & & & & & \\
\hline R52 & & & 1 & $35-40$ & & & & \\
\hline R53 & 1 & $<0.5 \mathrm{yrs}$ & & & & & 1 & $30-50$ \\
\hline R54 & & & 1 & $35-45$ & & & & \\
\hline R55 & & & & & & & 1 & $25-30$ \\
\hline R57 & & & 1 & $30-40$ & 1 & $30-40$ & & \\
\hline R58 & 1 & $<0.5 \mathrm{yrs}$ & & & & & 1 & $20-40$ \\
\hline R61 & & & & & 1 & $35-40$ & & \\
\hline R62 & & & 1 & $20-30$ & & & & \\
\hline \multirow[t]{2}{*}{ R63 } & 1 & $<6 \mathrm{mos}$ & & & & & 1 & $20-60$ \\
\hline & 1 & $1.5 \mathrm{yrs}$ & & & & & & \\
\hline R64 & & & & & & & 1 & $25-30$ \\
\hline R65 & & & & & & & 1 & $20-40$ \\
\hline R66 & & & & & & & 1 & $25-30$ \\
\hline R67 & & & & & & & 1 & $20-50$ \\
\hline R68 & 1 & $0.5 \mathrm{yrs}$ & 1 & $30-35$ & & & & \\
\hline
\end{tabular}


Continue Table 2.

\begin{tabular}{|c|c|c|c|c|c|c|c|c|}
\hline R69 & 1 & $0.5 \mathrm{yrs}+$ & & & & & & \\
\hline R72 & 1 & $1.5 \mathrm{yrs}$ & & & & & & \\
\hline R73 & 1 & $<0.5 \mathrm{yrs}$ & & & & & & \\
\hline R74 & & & & & 1 & $20-40$ & & \\
\hline R75 & & & & & 1 & $30-50$ & & \\
\hline R77 & 1 & $1.5 \mathrm{yrs}$ & & & & & & \\
\hline R78 & 1 & $<0.5 \mathrm{yrs}$ & & & & & & \\
\hline R80 & & & 1 & $30-40$ & & & & \\
\hline R81 & & & 1 & $30-35$ & & & & \\
\hline R82 & & & & & & & 1 & $20-60$ \\
\hline R83 & 1 & $<0.5 \mathrm{yrs}$ & 1 & $20-50$ & 1 & $20-50$ & & \\
\hline R84 & & & & & & & 1 & $20-60$ \\
\hline R85 & & & 1 & $30-35$ & & & & \\
\hline R86 & & & & & 1 & $30-40$ & & \\
\hline R87 & 1 & $1.5-2 \mathrm{yrs}$ & & & & & & \\
\hline \multirow[t]{2}{*}{ R88 } & & & & & & & 1 & $20-50$ \\
\hline & & & & & & & 1 & $20-50$ \\
\hline R89 & 1 & $<0.5 \mathrm{yrs}$ & & & & & 1 & $20-40$ \\
\hline R91 & & & & & 1 & $35-50$ & & \\
\hline Proc. 148 & & & & & & & 1 & $20-60$ \\
\hline
\end{tabular}

nine were incisors (representing $9.89 \%$ of recovered incisors), three were canines (representing $5.56 \%$ of recovered canines), 11 were premolars (representing $11.46 \%$ of recovered premolars), and 17 were molars (representing $15.32 \%$ of recovered molars).

Calculus deposits were present on most teeth, equally distributed between the buccal and lingual surfaces. Most calculus deposits were of only slight amount.

Table 4 also reveals the extent of teeth absent antemortem. Evidence of antemortem loss consisted of tooth absence accompanied by remodeling of the bony alveolus. Of all observations of teeth present or absent, $66(18.75 \%)$ were absent antemortem. Of the teeth absent antemortem, six were incisors, two were canines, 21 were premolars, and 37 were molars.

Seventeen alveolar abscesses were noted (10.06\%). These abscesses were present primarily in posterior teeth (premolars and molars). One abscess was associated with an incisor, zero were found associated with canines, seven were found in association with premolars, and nine were found in association with molars.

\section{Rasgos}

Evidence of bone pathology consisted primarily of healed trauma and periosteal reactive bone. Specific examples are as follows:

\section{Rasgo 5 (adult female)}

Field notes relating to this feature refer to a primary adult burial in a supine position with east-west orientation. Three spindle whorls were located on the right side of the skeleton. Shark teeth and small red shell beads were present on the left side.

Most major elements of the skeleton are present. Female sex is suggested by a femoral head maximum diameter of $39 \mathrm{~mm}$ and general morphological features, including an extremely prominent preauricular sulcus on both the left and right ilia.

An age at death between 40 and 50 years is suggested by the extent of dental attrition (Hrdlička 1939) and vertebral osteophytosis.

Although fragmentary, considerable reconstruction of skeletal elements was possible for both clavicles, both ulnae, both radii, both femora, the left humerus, and both fibulae diaphyses.

Diaphyses of both fibulae reveal extensive well-remodeled bone and abnormal, pathological morphology at what appear to be the distal segment ends. The reconstructed segments measure 106 $\mathrm{mm}$ and $110 \mathrm{~mm}$. Both segments show abnormal morphology and were originally longer as suggested by postmortem breaks on the non-pathological ends. The bones appear porous and light in weight suggesting an 


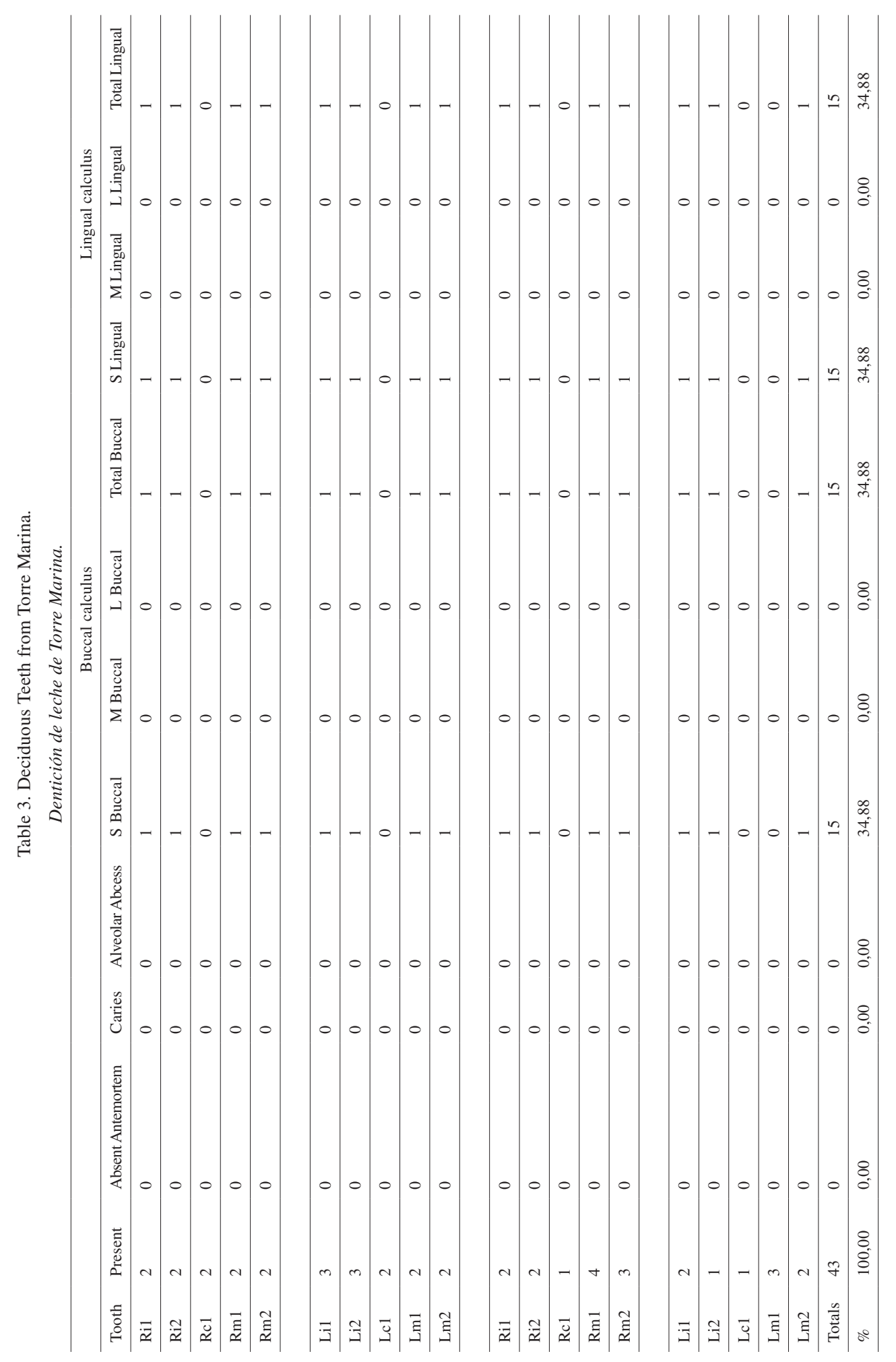


Table 4. Permanent Teeth from Torre Marina.

Dentición permanente de Torre Marina.

\begin{tabular}{|c|c|c|c|c|c|c|c|c|c|c|c|c|}
\hline Tooth & Present & $\begin{array}{c}\text { Absent } \\
\text { Antemortem }\end{array}$ & Caries & $\begin{array}{l}\text { Alveolar } \\
\text { Abscess }\end{array}$ & $\begin{array}{c}\text { S } \\
\text { Buccal }\end{array}$ & $\begin{array}{c}\text { M } \\
\text { Buccal }\end{array}$ & $\begin{array}{c}\mathrm{L} \\
\text { Buccal }\end{array}$ & $\begin{array}{l}\text { Total } \\
\text { Buccal }\end{array}$ & $\begin{array}{c}\mathrm{S} \\
\text { Lingual }\end{array}$ & $\begin{array}{c}\mathrm{M} \\
\text { Lingual }\end{array}$ & $\begin{array}{c}\mathrm{L} \\
\text { Lingual }\end{array}$ & $\begin{array}{c}\text { Total } \\
\text { Lingual }\end{array}$ \\
\hline RI1 & 16 & 0 & 3 & 0 & 16 & 0 & 0 & 16 & 16 & 0 & 0 & 16 \\
\hline RI2 & 16 & 1 & 0 & 0 & 15 & 1 & 0 & 16 & 15 & 1 & 0 & 16 \\
\hline $\mathrm{RC} 1$ & 16 & 0 & 2 & 0 & 15 & 1 & 0 & 16 & 16 & 0 & 0 & 16 \\
\hline RPM1 & 16 & 0 & 2 & 0 & 15 & 1 & 0 & 16 & 15 & 1 & 0 & 16 \\
\hline RPM2 & 10 & 1 & 0 & 0 & 10 & 0 & 0 & 10 & 10 & 0 & 0 & 10 \\
\hline RM1 & 8 & 1 & 1 & 0 & 7 & 1 & 1 & 9 & 7 & 0 & 0 & 7 \\
\hline RM2 & 6 & 1 & 0 & 1 & 6 & 0 & 1 & 7 & 5 & 0 & 0 & 5 \\
\hline RM3 & 12 & 1 & 2 & 1 & 11 & 0 & 0 & 11 & 11 & 0 & 0 & 11 \\
\hline LI1 & 11 & 0 & 1 & 0 & 11 & 0 & 0 & 11 & 11 & 0 & 0 & 11 \\
\hline LI2 & 9 & 0 & 2 & 0 & 8 & 1 & 0 & 9 & 9 & 0 & 0 & 9 \\
\hline $\mathrm{LC} 1$ & 16 & 0 & 0 & 0 & 16 & 0 & 1 & 17 & 15 & 0 & 0 & 15 \\
\hline LPM1 & 11 & 1 & 2 & 0 & 10 & 1 & 0 & 11 & 10 & 1 & 0 & 11 \\
\hline LPM2 & 11 & 2 & 3 & 0 & 11 & 0 & 0 & 11 & 11 & 0 & 0 & 11 \\
\hline LM1 & 14 & 2 & 1 & 0 & 13 & 1 & 0 & 14 & 14 & 0 & 0 & 14 \\
\hline LM2 & 7 & 2 & 2 & 0 & 7 & 0 & 0 & 7 & 7 & 0 & 0 & 7 \\
\hline LM3 & 9 & 1 & 1 & 0 & 8 & 0 & 1 & 9 & 8 & 0 & 0 & 8 \\
\hline RI1 & 13 & 2 & 1 & 0 & 13 & 0 & 0 & 13 & 13 & 0 & 0 & 13 \\
\hline $\mathrm{RI} 2$ & 12 & 0 & 1 & 0 & 10 & 1 & 0 & 11 & 10 & 1 & 0 & 11 \\
\hline $\mathrm{RC} 1$ & 13 & 2 & 1 & 0 & 13 & 0 & 1 & 14 & 12 & 0 & 0 & 12 \\
\hline RPM1 & 16 & 3 & 2 & 1 & 16 & 0 & 0 & 16 & 16 & 0 & 0 & 16 \\
\hline RPM2 & 14 & 6 & 1 & 2 & 14 & 0 & 0 & 14 & 14 & 0 & 0 & 14 \\
\hline RM1 & 15 & 3 & 4 & 0 & 15 & 0 & 0 & 15 & 15 & 0 & 0 & 15 \\
\hline RM2 & 10 & 6 & 0 & 1 & 8 & 2 & 0 & 10 & 8 & 2 & 0 & 10 \\
\hline RM3 & 10 & 5 & 2 & 2 & 9 & 0 & 0 & 9 & 9 & 0 & 0 & 9 \\
\hline LI1 & 7 & 3 & 1 & 1 & 7 & 0 & 0 & 7 & 7 & 0 & 0 & 7 \\
\hline LI2 & 7 & 0 & 0 & 0 & 6 & 0 & 0 & 6 & 6 & 0 & 0 & 6 \\
\hline $\mathrm{LC} 1$ & 9 & 0 & 0 & 0 & 9 & 0 & 0 & 9 & 9 & 0 & 0 & 9 \\
\hline LPM1 & 10 & 3 & 1 & 1 & 10 & 0 & 0 & 10 & 10 & 0 & 0 & 10 \\
\hline LPM2 & 8 & 5 & 0 & 3 & 8 & 0 & 0 & 8 & 8 & 0 & 0 & 8 \\
\hline LM1 & 6 & 7 & 0 & 2 & 6 & 0 & 0 & 6 & 6 & 0 & 0 & 6 \\
\hline LM2 & 7 & 5 & 3 & 2 & 6 & 0 & 0 & 6 & 6 & 0 & 0 & 6 \\
\hline LM3 & 7 & 3 & 1 & 0 & 7 & 0 & 0 & 7 & 7 & 0 & 0 & 7 \\
\hline Totals & 352 & 66 & 40 & 17 & 336 & 10 & 5 & 351 & 336 & 6 & 0 & 342 \\
\hline$\%$ & 85,56 & 13,87 & 11,36 & 10,06 & 95,45 & 2,84 & 1,42 & 99,72 & 95,45 & 1,70 & 0,00 & 97,16 \\
\hline
\end{tabular}


osteoporotic condition. The most likely interpretation of the missing distal ends accompanied by osteoporosis and well-remodeled bone at the ends of the segments is antemortem amputation. The evidence suggests antemortem amputation of both lower limbs in the area of the distal fibulae slightly above the ankle area. The coastal location of the site and the presence of shark teeth associated with the burial suggest that antemortem shark injury should be considered.

\section{Rasgo 7 (adult male)}

Elements of both arms, both legs, the axial skeleton, pelvis, and the hands and feet of the skeleton are represented.A narrow sciatic notch on the left innominate, lack of a preauricular sulcus, and a femoral head diameter of $49 \mathrm{~mm}$ indicate male sex. An age at death between 25 - 30 years is suggested by the extent of dental attrition. Bone pathology consists of well-remodeled reactive bone on both fibulae diaphyses and the left tibia diaphysis, concentrated on the distal halves of the bones.

\section{Rasgo 11 (adult female)}

Both first metatarsals and associated proximal foot phalanges display alterations associated with hyperdorsiflexion of the toe, probably resulting from habitual kneeling.

\section{Rasgo 43 (adult female)}

The left distal humerus displays extensive arthritic alteration likely associated with antemortem trauma. In addition, the left third metatarsal and one proximal foot phalanx present extensive alterations associated with hyperdorsiflexion of the toes probably resulting from a habitual kneeling posture.

\section{Rasgo 48 (adult female)}

Alterations relating to hyperdorsiflexion of the toes probably resulting from a habitual kneeling posture are present on the first left metatarsal.

\section{Rasgo 54 (adult male)}

One proximal and one middle hand phalanx are fused together with the middle phalanx displaced toward the posterior. The alteration is well-remodeled and likely results from trauma.

\section{Rasgo 84 (adult of unknown sex)}

A femoral fragment presents evidence of very well remodeled reactive bone.
Examples of vertebral osteophytosis and other agerelated alterations were present but not listed individually above. No examples of porotic hyperostosis or cribra orbitalia were present. The fragmentary nature of the remains precluded accurate estimates of living stature.

Three adult females in the Torre Marina sample presented alterations on the metatarsals and proximal foot phalanges suggesting a habitual kneeling posture. Such alterations were first reported in Ecuador from the Ayalán (Late Integration) skeletal sample in Guayas Province (Ubelaker 1981). In the Ayalán sample the alterations also appeared to be associated with adult females with interpretation centering on a kneeling posture during food preparation (Ubelaker 1979, 1985). A similar interpretation seems likely with the foot bone alterations discovered in the Torre Marina sample.

\section{Discussion}

The new data revealed in the Torre Marina sample analysis can best be interpreted in the context of previously published comparative data on health and demography from Ecuador. Table 5 presents the chronological sequence of published large skeletal samples from Ecuador including the Torre Marina population. These coastal and highland samples range chronologically from the preceramic Santa Elena complex (8250-6600 BP) to the Convento de San Francisco in Quito as recent as 100-10 BP. Such geographical and temporal depth provides rich comparative context and reveals key trends in the evolution of morbidity and mortality within Ecuador.

\section{Trauma}

Evidence of antemortem trauma was confined to four bones from two adult individuals, one male and one female. All examples displayed extensive remodeling suggesting the traumatic event occurred many years prior to death. This suggests a ratio of bones with trauma to the number of adults in the sample of $4: 55$ or $7.27 \%$. Comparative data ratios of bones with trauma to the number of adults in a sample population are presented in Figure 2.

\section{Periosteal lesions}

Four bones presented evidence of well-remodeled periosteal lesions. Three of these originated from Rasgo 7, an adult male and one from Rasgo 84, an adult of unknown sex. These examples suggest a ratio of bones with periosteal lesions to the number of adults of 4:55 or $7.27 \%$. The ratio of bones with periosteal lesions to the total number of individuals is $4: 79$ or $5.06 \%$. 
Table 5. Chronological large published samples from Ecuador.

Muestras del Ecuador publicadas en orden cronológico.

\begin{tabular}{|c|c|c|c|c|c|}
\hline & Site & No. of Samples & Date & Location & Culture \\
\hline Preceramic & Santa Elena complex & 192 & $8250-6600$ BP & Guayas & Vegas complex \\
\hline Early Formative & Real Alto & 100 & $3400-1500 \mathrm{BCE}$ & Guayas & Valdivia \\
\hline \multirow{7}{*}{$\begin{array}{l}\text { Intermediate } \\
\text { Precontact }\end{array}$} & Cotocollao & 199 & $1000-500 \mathrm{BCE}$ & Pichincha & Cotocollao \\
\hline & La Libertad (OGSE-46) & 24 & $900-200 \mathrm{BCE}$ & Guayas & Engoroy \\
\hline & Early La Tolita & 7 & $600-200 \mathrm{BCE}$ & Esmeraldas & Early Tolita \\
\hline & Cumbayá & 20 & $400 \mathrm{BCE}-100 \mathrm{CE}$ & Pichincha & Cumbayá \\
\hline & OGSE-MA-172 & 30 & $100 \mathrm{BCE}$ & Guayas & Guangala \\
\hline & Classic La Tolita & 20 & $200 \mathrm{BCE}-90 \mathrm{CE}$ & Esmeraldas & Classic Tolita \\
\hline & Late La Tolita & 54 & 90-400 CE & Esmeraldas & Late Tolita \\
\hline \multirow[t]{5}{*}{ Late Precontact } & Ayalán (non-urn) & 51 & $500 \mathrm{BCE}-1155 \mathrm{CE}$ & Guayas & Milagro \\
\hline & La Florida & 76 & $340 \mathrm{CE}$ & Pichincha & Chaupicruz \\
\hline & Agua Blanca & 7 & $800-1500 \mathrm{CE}$ & Manabi & Manteno \\
\hline & Torre Marina & 79 & $600-1000 \mathrm{CE}$ & Guayas & Guangala \\
\hline & Ayalán (urn) & 384 & $730-1730 \mathrm{CE}$ & Guayas & Milagro \\
\hline \multirow[t]{5}{*}{ Early Historic } & $\begin{array}{l}\text { Convento de San } \\
\text { Francisco }\end{array}$ & Hallway: 60 & $1500-1570 \mathrm{CE}$ & Pichincha & Historic \\
\hline & Santo Dominigo & 46 & $1500-1650 \mathrm{CE}$ & Pichincha & Historic \\
\hline & \multirow{3}{*}{$\begin{array}{l}\text { Convento de San } \\
\text { Francisco }\end{array}$} & Strata cut, upper level : 74 & $1540-1650 \mathrm{CE}$ & Pichincha & Historic \\
\hline & & Strata cut, lower level: 46 & $1580-1700 \mathrm{CE}$ & Pichincha & Historic \\
\hline & & Atrium: 19 & $1600-1725 \mathrm{CE}$ & Pichincha & Historic \\
\hline \multirow[t]{5}{*}{ Late Historic } & Convento de San Fracisco & Church: 119 & $1535-1858 \mathrm{CE}$ & Pichincha & Historic \\
\hline & & $\begin{array}{l}\text { Superficial collection, lower } \\
\text { level: } 52\end{array}$ & $1670-1709 \mathrm{CE}$ & Pichincha & Historic \\
\hline & & Main cloister: 33 & $1730-1858 \mathrm{CE}$ & Pichincha & Historic \\
\hline & & $\begin{array}{l}\text { Superfcial collection, upper } \\
\text { level: } 21\end{array}$ & $1770-1890 \mathrm{CE}$ & Pichincha & Historic \\
\hline & & Boxes: 33 & $1850-1940 \mathrm{CE}$ & Pichincha & Historic \\
\hline
\end{tabular}

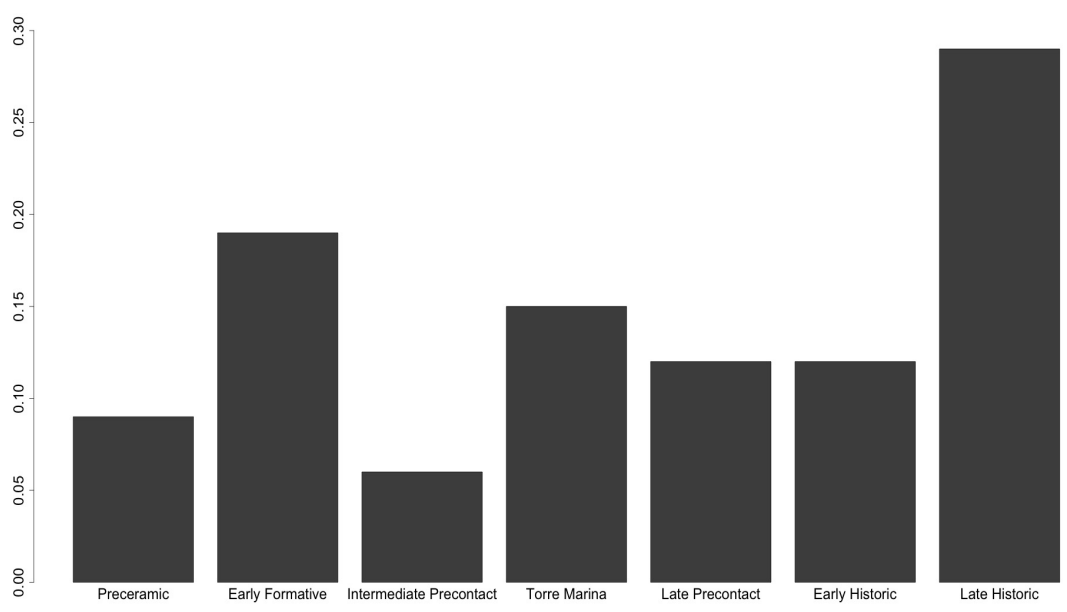

Figure 2. Temporal change in the ratio of bones with trauma to the number of adults. Cambio temporal en la proporción de huesos con trauma con el número de adultos. 


\section{Porotic hyperostosis}

No examples of porotic hyperostosis of the cranial vault or the related condition of cribra orbitalia were noted. While this could reflect the fragmentation of the sample and the resulting difficulty in making such observations, the absence is noteworthy. The only other published Guangala sample (OGSE-MA-172) revealed a very high prevalence of porotic hyperostosis. Interpretation of the elevated levels of porotic hyperostosis at OGSE-MA-172 centered on anemia produced by hookworm infestation (Ubelaker 1992b). Lack of this condition in the Torre Marina sample weakens that argument or suggests the infestation was local and not shared more generally.

\section{Dental hypoplasia}

Only two hypoplastic teeth $(0.06 \%$ of recovered permanent teeth) were found at the Torre Marina site. One from R16, a 30-35 year old male (displaying hypoplastic defects that formed around age 3 ) and one from R 91, a 35-50 year old female (displaying hypoplastic defects which also formed around 3 years of age). The frequency for this sample is relatively very low for Ecuadorean samples analyzed from all periods (Ubelaker 1992a). These values range from $0.5 \%$ in the Late Historic samples to $4.4 \%$ in the Late Precontact period. Comparative values for temporal change in the frequency of dental hypoplasia in Ecuador are presented in Figure 3.

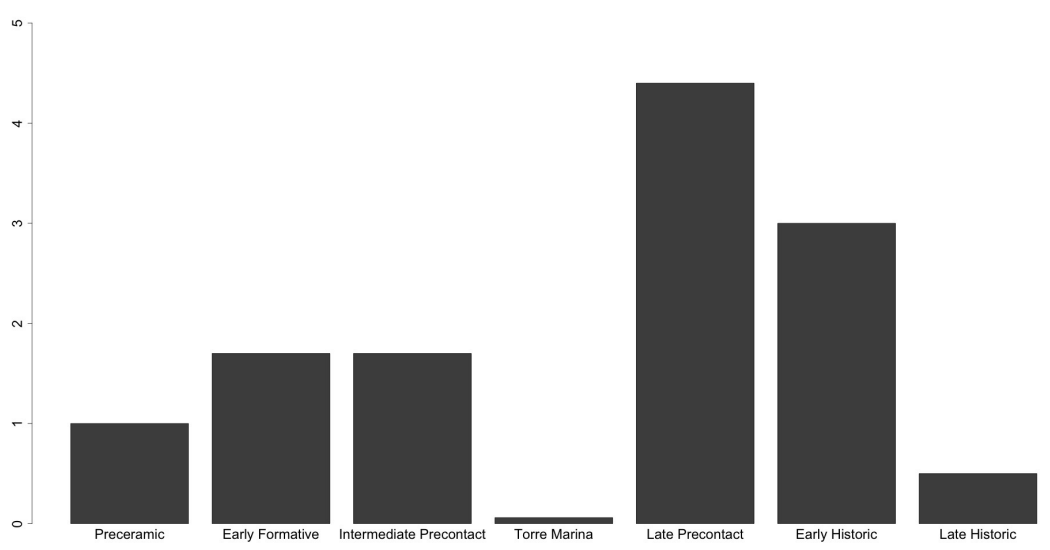

Figure 3. Temporal change in the frequency of dental hypoplasia.

Cambio temporal en la frecuencia de hipoplasia dental.

\section{Dental caries}

As noted in Figure 4, the prevalence of dental caries is relatively high, especially compared to other Intermediate Precontact samples. In this sample, a total of 40 carious teeth were recovered. Sixteen carious teeth $(40 \%)$ were associated with male remains, $19(47.5 \%)$ were associated with female remains, and five $(12.5 \%)$ were associated with remains of indeterminate sex. No recovered deciduous teeth presented caries. Presence of dental caries relates closely to diet, in particular consumption of maize or other starchy foods (Larsen et al. 1991). Dental caries results from destruction of the tooth surface when bacteria colonize the area. The relatively high values are consistent with a maize-based diet since maize consumption promotes this process (Ubelaker 1992a). Data from other periods revealed in Figure 4 indicate that the relationship of dental caries with maize consumption is complex.

\section{Alveolar abscesses}

Alveolar abscesses represent bony lesions in the maxillary or mandibular alveolus associated with teeth. Seven abscesses $(41.18 \%)$ were observed on male remains and ten $(58.82 \%)$ were observed on female remains. No abscesses were observed on remains of indeterminate sex or subadults. Abscesses result when the pulp chamber of the tooth is exposed due to destruction by attrition and/or caries. Once the pulp chamber is exposed, bacteria travel from the oral cavity to the root of the tooth and colonize. This bacteria colonization may result in bone destruction.

Figure 5 presents the prevalence of alveolar abscesses for the Torre Marina sample compared to other samples reported for Ecuador and reveals that the prevalence in the Torre Marina sample is the highest reported. Such a high value likely reflects the combined effect of a high prevalence of dental caries, coupled with significant dental attrition. 

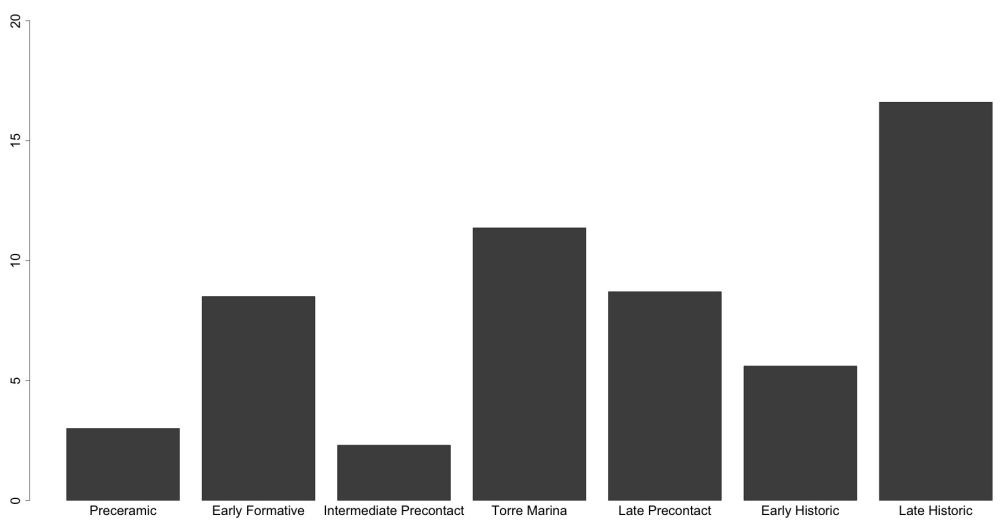

Figure 4. Temporal change in the frequency of dental caries.

Cambio temporal en la frecuencia de caries.
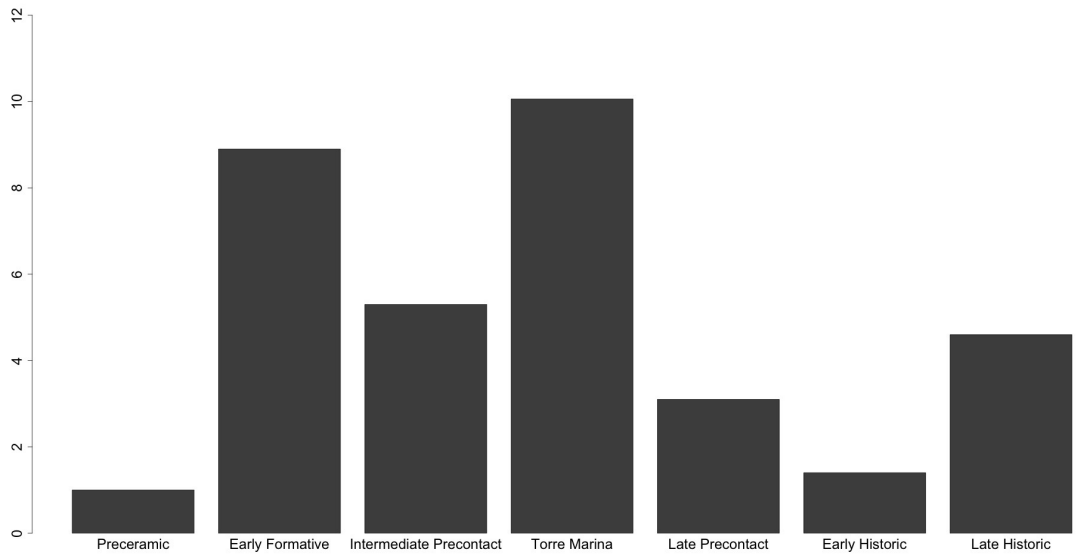

Figure 5. Temporal change in the frequency of alvealor abscesses. Cambio temporal en la frecuencia de abcesos alveolares. 


\section{Antemortem tooth loss}

Antemortem tooth loss is the predictable result of untreated alveolar abscesses if the individual lives long enough. Torre Marina males lost a total of 26 (39.39\%) permanent teeth antemortem while females lost a total of $38(57.57 \%)$. The remaining two teeth $(3.04 \%)$ lost antemortem were from skulls of indeterminate sex. No subadult skulls showed evidence of antemortem permanent tooth loss. The high prevalence of alveolar abscesses in the Torre Marina sample explains the also high prevalence of antemortem tooth loss. Comparative data from Figure 6 reveal that antemortem tooth loss in the Torre Marina sample is the highest value for precontact Ecuador.

\section{Life expectancy}

The life table (Table 1) reveals a relatively high life expectancy for the population represented by the Torre Marina sample. Figure 7 presents comparative values of life expectancy at birth. The Torre Marina sample emerges from this comparison with the highest overall life expectancy. Similar high comparative values are revealed in life expectancy at age 5 (Figure 8 ) with similarly high life expectancy during the Late Precontact. These two figures reflect the comparatively lower infant mortality in the Torre Marina sample.

Figure 9 presents comparative data on life expectancy at age 15. In this comparison, without consideration of subadult mortality, the Torre Marina sample remains among the highest for the precontact samples but considerably lower than reported for the Early Historic. Adult longevity was clearly increasing during the Guangala period reported but did not reach its peak until the early historic period.

\section{Conclusions}

Although the Torre Marina sample presented considerable fragmentation, it offers valuable comparative data from the Guangala Phase of the Regional Development/Early Integration Period. These data suggest moderate levels of trauma and relatively low prevalence of periosteal lesions and porotic hyperostosis. In contrast, analysis suggests high levels of dental caries, alveolar abscesses, and antemortem loss of permanent teeth. Life expectancy at birth and at age 15 was comparatively high.

Compared to other samples from prehistoric and historic Ecuador, the population represented by the Torre Marina sample experienced low levels of childhood disease and nutritional issues. Evidence of infection producing periosteal lesions was also minimal for all ages. These indicators suggest relatively good health resulting in high life expectancy.

The negative trends all relate to dental disease, likely linked closely with diet and nutrition, especially maize consumption. The high prevalence of permanent teeth with carious lesions suggests consumption of cariogenic foods. Dental caries coupled with extensive dental occlusal attrition (likely linked to techniques of food preparation) led to a high prevalence of antemortem loss of permanent teeth. Tooth loss reflects extensive dental disease along with elevated adult longevity and life expectancy.
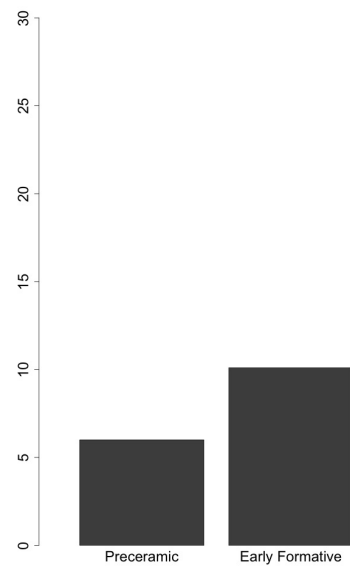
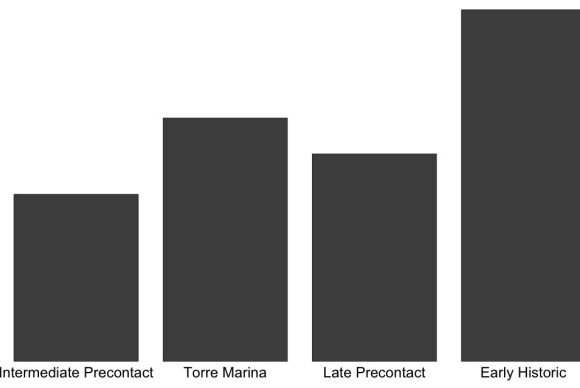

Early Historic

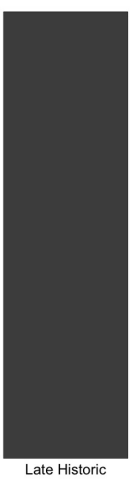

Figure 6. Temporal change in the frequency of antemortem tooth loss. 


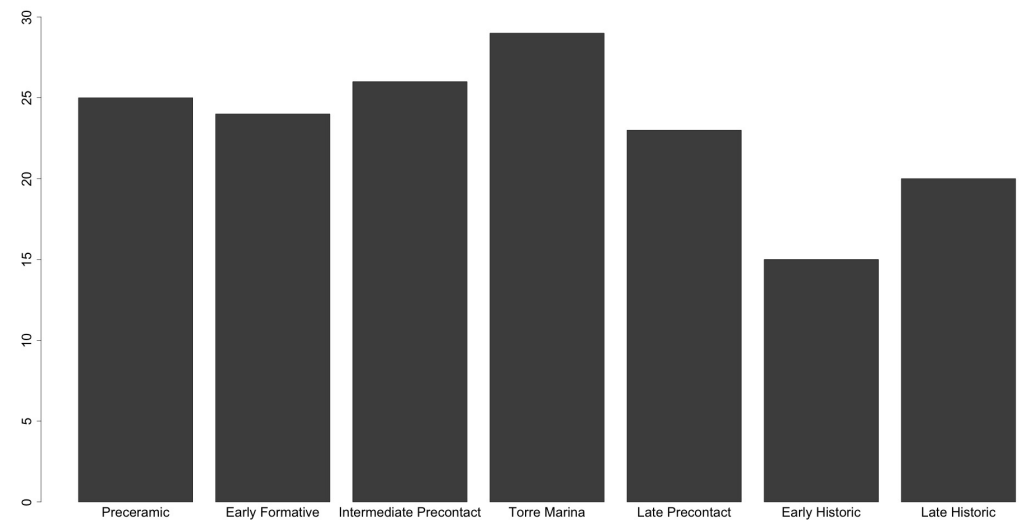

Figure 7. Temporal change in life expectancy at birth.

Cambio temporal en la expectativa de vida al nacer.
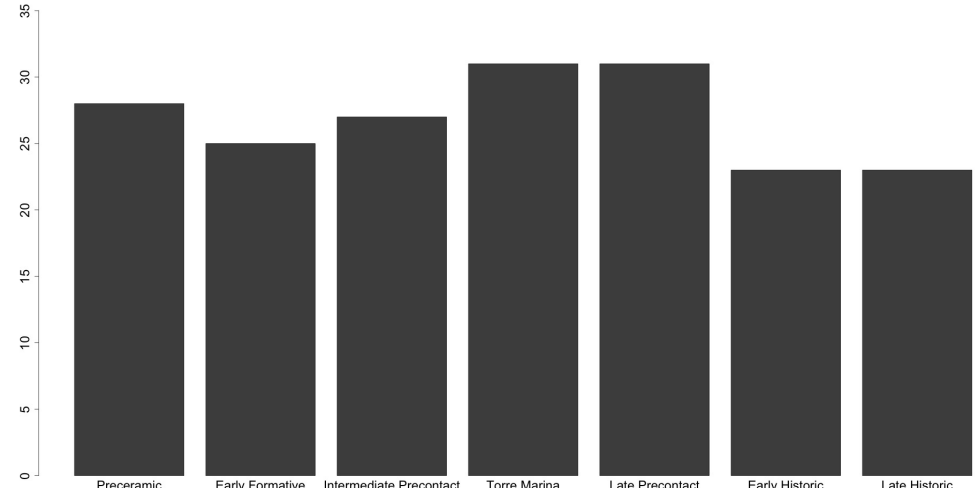

Figure 8. Temporal change in life expectancy at age 5 .

Cambio temporal en la expectativa de vida a los 5 años.
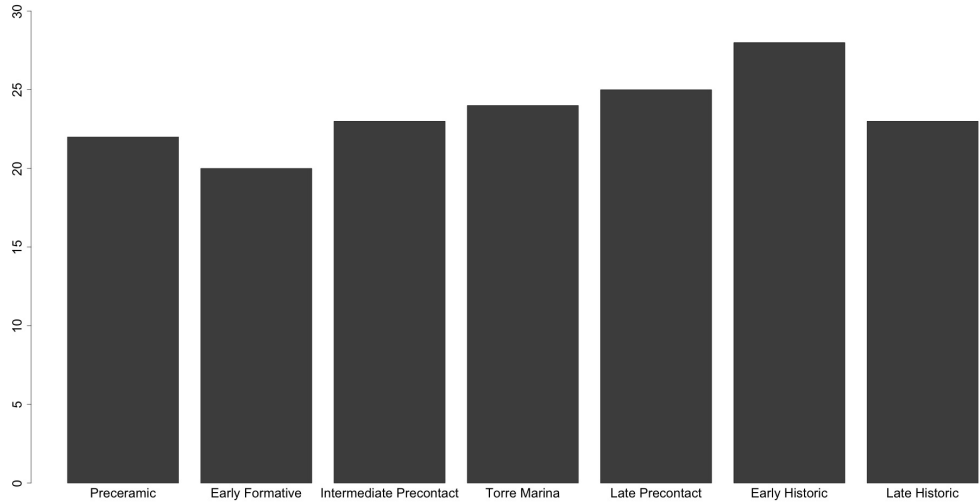

Figure 9. Temporal change in life expectancy at age 15.

Cambio temporal en la expectativa de vida a los 15 años. 
These new data provide an important addition to the growing assemblage of information regarding health and disease in ancient Ecuador. The general trend suggests increasing morbidity and mortality with time but with significant regional and site variation.
Acknowledgements: Dr. Karen Stothert generously provided access to a workspace and the Torre Marina sample. The map was prepared by M. Bakry at the Smithsonian Institution. The authors would also like to thank Sara C. Zapico for her assistance in translation, and to the anonymous evaluators of Chungara.

\section{References Cited}

Buikstra, J.E. and D.H. Ubelaker (eds.) 1994. Standards for Data Collection from Human Skeletal Remains. Arkansas Archaeological Survey Research Series No. 44. Arkansas Archaeological Survey, Fayetteville.

Larsen, C.S., R. Shavit, and M.C. Griffin 1991. Dental caries evidence for dietary change: An archaeological context. In Advances in Dental Anthropology, edited by M.A. Kelley and C. Spencer Larsen, pp. 179-202. Wiley-Liss, New York.

Piperno, D.R. and K.E. Stothert 2003. Phytolith evidence for Early Holocene Cucurbita domestication in Southwest Ecuador. Science 229:1054-1057.

Reitz, E.J. and M.A. Masucci 2004. Guangala Fishers and Farmers: A Case Study of Animal Use at El Azúcar, Southwestern Ecuador. University of Pittsburgh Memoirs in Latin American Archaeology. Vol. 14.

Stothert, K.E. 1983. Review of the Early Preceramic complexes of the Santa Elena Peninsula, Ecuador. American Antiquity 48:122-127.

Stothert, K.E. 1985. The Preceramic Las Vegas culture of Coastal Ecuador. American Antiquity. 50:613-637.

Stothert, K.E., D.R. Piperno, and T.C. Andres 2003. Terminal Pleistocene/Early Holocene adaptation in coastal Ecuador: The Las Vegas evidence. Quaternary International 109:23-43.

Tellkamp, M.P. 2019. A story told from a small-mesh screen: the importance of songbirds and ground doves to the Guangala people at the El Azúcar archaeological site in coastal Ecuador. Archaeological and Anthropological Sciences 1-11.

Ubelaker, D.H. 1979. Skeletal evidence for kneeling in Prehistoric Ecuador. American Journal of Physical Anthropology 51:679-685.

Ubelaker, D.H. 1980a. Human skeletal remains from Site OGSE80, a Preceramic site on the Sta. Elena Peninsula, Coastal Ecuador Journal of the Washington Academy of Sciences 70:3-24.

Ubelaker, D.H. 1980b. Prehistoric human remains from the Cotocollao Site, Pichincha Province, Ecuador. Journal of the Washington Academy of Sciences 70:59-74.

Ubelaker, D.H. 1981. The Ayalán Cemetery: A Late Integration Period Burial Site on the South Coast of Ecuador. Smithsonian Contributions to Anthropology 29. Smithsonian Institution Press, Washington D.C.

Ubelaker, D.H. 1983. Human skeletal remains from OGSA-Ma-172: An Early Guangala Cemetery Site on the Coast of Ecuador. Journal of the Washington Academy of Sciences 73:16-27.

Ubelaker, D.H. 1984. Prehistoric human biology of Ecuador: Possible temporal trends and cultural correlations. In Paleopathology at the Origins of Agriculture, edited by M. Nathan Cohen and G.J. Armelagos, pp. 491-513. Academic Press, New York.

Ubelaker,D.H. 1985. Evidencia esquelética de postura arrodillada en el Ecuador. Miscelánea Antropológica Ecuatoriana, Boletín de los Museos del Banco Central del Ecuador 5:35-46.
Ubelaker, D.H. 1988a. Human Remains from OGSO-46, La Libertad, Guayas Province, Ecuador. Journal of the Washington Academy of Sciences 78:3-16.

Ubelaker, D.H. 1988b. A preliminary report of human remains from Agua Blanca, a Prehistoric Late integration Site from Coastal Ecuador. Journal of the Washington Academy of Sciences 78:17-22.

Ubelaker, D.H. 1988c. Prehistoric human biology at La Tolita, Ecuador, a preliminary report. Journal of the Washington Academy of Sciences 78:23-37.

Ubelaker, D.H. 1988d. Restos humanos prehistóricos del Sitio Cotocollao, Provincia del Pichincha, Ecuador. En Cotocollao: Una Aldea Formativa del Valle de Quito, edited by M. Villalba, Appendix II. 557-571. Miscelánea Antropológica Ecuatoriana, Serie Monográfica 2. Museos del Banco Central del Ecuador, Quito.

Ubelaker, D.H. 1990a. Human Skeletal Remains from "Jardín del Este", Cumbaya, Pichincha, Ecuador. In La Preservación y Promoción del Patrimonio Cultural del Ecuador, pp. 2239. Cooperación Técnica Ecuatoriana - Belga No. 4. Instituto Nacional de Patrimonio Cultural, Quito.

Ubelaker, D.H. 1990b. Restos humanos provenientes de "Jardín del Este", Cumbaya, Pichincha, Ecuador. In La Preservación y Promoción del Patrimonio Cultural del Ecuador, pp. 40-52. Cooperación Técnica Ecuatoriana - Belga No. 4. Instituto Nacional de Patrimonio Cultural, Quito.

Ubelaker, D.H. 1992a. Patterns of biological change in Ancient Ecuador (Abstract). American Journal of Physical Anthropology. Supplement 14:165.

Ubelaker, D.H. 1992b. Porotic hyperostosis in Prehistoric Ecuador. In Diet, Demography, and Disease: Changing Perspectives on Anemia, edited by P. Stuart-Macadam and S. Kent, pp. 201-217. Aldine de Gruyter, New York.

Ubelaker, D.H. 1994a. Biología de los Restos Humanos Hallados en el Convento de San Francisco. Instituto Nacional de Patrimonio Cultural del Ecuador. Journal of the Washington Academy of Sciences.

Ubelaker, D.H. 1994b. The biological impact of European Contact in Ecuador. In In the Wake of Contact: Biological Responses to Conquest, edited by C. Spencer Larsen and G.R. Milner, pp. 147-160. Wiley-Liss, New York.

Ubelaker, D.H. 1995. Osteological and archival evidence for disease in Historic Quito, Ecuador. In Grave Reflections, Portraying the Past through Cemetery Studies, edited by S.R. Saunders and A. Herring. 223-239. Canadian Scholars' Press Inc., Toronto.

Ubelaker, D.H. 1997. Skeletal Biology of Human Remains from La Tolita, Esmeraldas Province, Ecuador. Smithsonian Contributions to Anthropology 41. Smithsonian Institution Press, Washington, D.C. 
Ubelaker, D.H. 1999. Human Skeletal Remains: Excavation, Analysis, Interpretation. 3rd ed. Taraxacum, Washington, D.C.

Ubelaker, D.H. 2000. Human Skeletal Remains from La Florida, Quito, Ecuador. Smithsonian Contributions to Anthropology 43. Smithsonian Instiution Press, Washington, D.C.

Ubelaker, D.H. 2001. Weighting of age interval values in life table construction. Anthropologie XXXIX (1):9-13.

Ubelaker, D.H. 2003. Health issues in the Early Formative of Ecuador: Skeletal biology of Real Alto. In Archaeology of Formative Ecuador, edited by J.S. Raymond and R.L. Burger, pp. 259-287. Dumbarton Oaks Research Library and Collection, Washington, D.C.

Ubelaker, D.H. 2007. The Impact of the plague in Colonial Period Ecuador: The skeletal evidence. In Peste: Entre Épidémies et
Sociétés, edited by M. Signoli, D. Chevé, P. Adalian, G. Boëtsch, and O. Dutour, pp. 131-136. Firenze University Press, Firenze.

Ubelaker, D.H. and J.A. Freire 2005. The Distribution of calculus deposits in dentitions from Ancient Ecuador. Anthropologie 43:13.

Ubelaker, D.H., M.A. Katzenberg, and L.G. Doyon 1995. Status and diet in precontact Highland Ecuador. American Journal of Physical Anthropology 97:403-411.

Ubelaker, D.H. and L.A. Newson 2002. Patterns of health and nutrition in Prehistoric and Historic Ecuador. In The Backbone of History, Health, and Nutrition in the Western Hemisphere, edited by R.H. Steckel and J.C. Rose, pp. 343-374. Cambridge University Press, Cambridge.

Ubelaker, D.H. and A. Rousseau 1993. Human remains from the hospital San Juan de Dios, Quito, Ecuador. Journal of the Washington Academy of Sciences 83:1-8. 
